\title{
A REFORMA TRABALHISTA E SUAS IMPLICAÇÕES PARA O NORDESTE: primeiras reflexões
}

\author{
Roberto Véras de Oliveira * (https://orcid.org/0000-0001-7751-6863) \\ Mário Henrique Ladosky* * (http://orcid.org/0000-0002-6423-1196) \\ Maurício Rombaldi *** (https://orcid.org/0000-0002-0066-7708)
}

\begin{abstract}
Sob o discurso da necessidade de "modernização" das relações de trabalho no Brasil, a implementação da Reforma Trabalhista, em novembro de 2017, significou uma profunda mudança no paradigma da regulação das relações de trabalho no país. O objetivo deste artigo é analisar os efeitos da Reforma no Nordeste, pouco mais de um ano após a sua entrada em vigor. Em especial, busca-se observar em que medida esse padrão de regulação tem agravado desigualdades sociais. Para tanto, o foco do estudo reside em três setores econômicos de dois estados e seus respectivos sindicatos de trabalhadores: na Paraíba, abordamos o setor da construção civil e, em Pernambuco, a indústria automobilística e o segmento de tecnologias da informação. Para a pesquisa, foram utilizados dados da PNADC/IBGE, da RAIS, do CAGED, do Mediador/MTE e de questionários e entrevistas coletados em pesquisa da Rede de Estudos e Monitoramento Interdisciplinar da Reforma Trabalhista (REMIR).
\end{abstract}

PALAVRAS-CHAvE: Reforma Trabalhista. Trabalhadores. Sindicatos. Desigualdade. Nordeste.

\section{INTRODUÇÃO}

O Brasil vive, com a entrada em vigência da Reforma Trabalhista (Lei $\mathrm{n}^{\circ}$ 13.467) em novembro de 2017, ${ }^{1}$ uma mudança de paradigma na regulação das relações de trabalho (Cf. Véras de Oliveira, 2018). Sua aprovação ocorreu sob o discurso da modernização das relações de trabalho no país, uma vez que, datada da década de 1940, a legislação trabalhista estaria obsoleta frente às necessidades do capitalismo contemporâneo, que demandaria uma força de trabalho cada vez mais flexível.

Desde a década de 1990, com a adoção de políticas neoliberais e pressões em favor da flexibilização das relações de trabalho, passou

* Universidade Federal da Paraíba - UFPB. Departamento de Ciências Sociais. Programa de Pós-Graduação em Sociologia. Campus I - Lot. Cidade Universitaria. Cep: 58051-900. João Pessoa - Paraíba - Brasil. roberto.veras.2002@gmail.com

* * Universidade Federal de Campina Grande - UFCG. Unidade Acadêmica de Ciências Sociais e do Programa de Pós-Graduação em Ciências Sociais.

Rua Aprígio Veloso, 882 - Bairro Universitário. Cep: 58429-900. Campina Grande - Paraíba - Brasil. mhladosky@gmail.com

*** Universidade Federal da Paraíba - UFPB. Departamento de Ciências Sociais. Programa de Pós-Graduação em Sociologia Campus I - Lot. Cidade Universitaria. Cep: 58051-900. João Pessoa - Paraíba - Brasil. mauricio.rombaldi@gmail.com

${ }^{1}$ Aprovada em julho do mesmo ano. a ser recorrente a defesa de uma reforma na legislação trabalhista, por parte de entidades empresariais e de seus representantes no parlamento. Apesar de sucessivas alterações, desde então, na Consolidação das Leis do Trabalho (CLT) (Cf. Baltar et al., 2010; Krein, 2007), não havia ocorrido uma mudança profunda nos fundamentos do sistema varguista tal como a experimentada em 2017.

Conforme estudo do CESIT (2017), a Reforma está assentada nos seguintes pilares: primazia do negociado sobre o legislado - que fragiliza o sistema de proteção social, atribuindo às "livres negociações" o poder de estabelecer condições menos vantajosas que a lei; incentivo à negociação individual entre empregador e empregado, em detrimento das negociações coletivas; legalização de contratos de trabalho precários - rebaixados em relação ao contrato de trabalho integral, por tempo indeterminado e dotado de garantias sociais; proibição da ultratividade das cláusulas negociadas; diminuição da participação estatal na resolução dos conflitos trabalhistas - esvaziando o caráter público da resolução de conflitos; desconfiguração da CLT - que, mesmo sob limites, 
instituiu um sistema de proteção de relações de trabalho no país; eliminação da principal fonte de financiamento dos sindicatos - o imposto sindical, descontado compulsoriamente do salário dos trabalhadores -, enfraquecendo seu poder de mobilização; imposição de maiores dificuldades de acesso dos trabalhadores à Justiça do Trabalho.

Embora uma real dimensão dos impactos da Reforma só seja possível passados alguns anos de sua implementação, já há indícios de suas consequências. $\mathrm{O}$ que se pretende, neste artigo, é analisar, pouco mais de um ano após a entrada em vigor da nova lei, os efeitos de sua implementação no Nordeste, com destaque para três setores econômicos situados em dois estados: na Paraíba, a construção civil, e, em Pernambuco, a indústria automobilística e o segmento de tecnologias da informação. Tais setores são distintos do ponto de vista das relações de trabalho e, embora seus respectivos sindicatos sejam vinculados à mesma central sindical, a Central Única dos Trabalhadores (CUT), são portadores de diferentes experiências sindicais.

A construção civil é um setor que, não obstante ter incorporado inovações tecnológicas e organizacionais, tem, principalmente no Nordeste, as marcas de processos produtivos $\rightarrow$ e de trabalho tradicionais. Na Paraíba, isso se manifesta em um regime produtivo intensivo em trabalho, com predomínio de trabalhadores com baixa qualificação e remuneração, assim como uma elevada informalidade. A alta concentração na Região Metropolitana de João Pessoa serviu de base para a constituição de : uma destacada tradição de organização sindical, expressa na trajetória do Sindicato dos Trabalhadores nas Indústrias da Construção e do Mobiliário de João Pessoa (SINTRICOM-JP), que teve e tem papel de destaque na organização da CUT na Paraíba.

Por outro lado, o setor automobilístico, no Nordeste, se resume a dois polos: um deles é capitaneado pela planta da Ford em Camaçari, na Bahia, e o outro, pela Fiat-Chrysler
(FCA), situado em Goiana, em Pernambuco. Aqui nos deteremos sobre o segundo. $\mathrm{O}$ que chama a atenção, nesse caso, é o caráter de enclave do complexo industrial, formado pelas plantas da automobilística e de seus fornecedores. De acordo com dados da Relação Anual de Informações Sociais (RAIS), na última década, o mercado de trabalho local foi fortemente impactado pelo Polo Automotivo, que elevou ao primeiro lugar a participação do setor da indústria de transformação no emprego formal e provocou alterações nos demais setores de atividade econômica. As mudanças, contudo, agravaram o caráter segmentado do mercado de trabalho local. Em sentido geral, pode-se falar em uma dupla segmentação. A primeira se verifica entre, de um lado, as condições e as relações de trabalho historicamente predominantes na região, com a presença da agroindústria da cana-de- açúcar e da agricultura familiar, além de um setor turístico e comercial assentado em pequenos negócios e no autoemprego, em geral informais; e, de outro, as novas condições e relações de trabalho trazidas com a chegada das plantas industriais da Hemobrás, ${ }^{2}$ da Vivix, ${ }^{3}$ da Fiat-Chrysler e de outras menores. A segunda segmentação se observa no interior dessas fábricas, entre um grupo restrito de trabalhadores qualificados e amplas maiorias de trabalhadores semiqualificados e com mais baixa remuneração. Os trabalhadores da Fiat-Chrysler estão na base do Sindicato dos Trabalhadores Metalúrgicos de Pernambuco (SINDMETAL-PE), o qual participou ativamente da criação da CUT em Pernambuco, mas que enfrenta dificuldades para avançar na sindicalização nas novas regiões industriais do Complexo Industrial Portuário de Suape e do Polo Automotivo de Goiana.

O segmento de TI do Nordeste, apesar de registrar crescimento significativo nas últimas décadas, encontra-se distante do patamar alcançado pela região Sudeste (Cf. Véras de

${ }^{2}$ Fábrica de produtos farmacêuticos hemoderivados.

${ }^{3}$ Fábrica de vidros temperados. 
Oliveira, 2019). No Nordeste, os polos mais importantes estão localizados nas regiões metropolitanas de Salvador, Recife e Fortaleza. Neste estudo, nos deteremos sobre o caso de Pernambuco, que abriga o Porto Digital de Recife, concentração de empresas com foco na produção de softwares. Quanto às relações de trabalho, o segmento incorpora trabalhadores com alta qualificação e alta escolaridade, marcadamente jovens, com remuneração bem acima da média do mercado de trabalho local. Nos anos 1980 e 1990, predominavam, no setor, empresas estatais como a Dataprev e o Serpro, onde, entre os trabalhadores, se destacava a ocupação de digitador. Atualmente, as empresas privadas representam ampla maioria, concentradas na produção de softwares, em que ganha destaque a ocupação de analista de sistemas. O Sindicato dos Trabalhadores em Empresas de Informática, Processamento de Dados e Tecnologia da Informação de Pernambuco (SINDPD-PE) é quem representa os trabalhadores do segmento, sendo esse um dos Sindicatos de maior destaque na CUT em Pernambuco.

O propósito deste artigo é analisar as implicações da Reforma Trabalhista no Nordeste, com foco nesses três setores e, com isso, poder lançar algumas reflexões sobre se a nova legislação tende a agravar as desigualdades sociais, marcas do Brasil e, ainda mais, do Nordeste. Como fontes, foram usados a Pesquisa Nacional por Amostra de Domicílios Contínua trimestral (PNADC) do IBGE; a Relação Anual de Informações Sociais (RAIS), o Cadastro Geral de Empregados e Desempregados (CAGED) e o Sistema Mediador, do extinto Ministério do Trabalho; os resultados da pesquisa sindical realizada pela Rede de Estudos e Monitoramento Interdisciplinar da Reforma Trabalhista (REMIR); além de entrevistas com sindicalistas.

O texto está organizado em três partes, além da Introdução e das Considerações Finais. A primeira trata das novas formas de contratação legalizadas pela Reforma Trabalhista. A segunda discute os impactos da Reforma sobre os processos de Negociação Coletiva. A úl- tima foca as implicações da Reforma sobre os Sindicatos e as primeiras estratégias de reação por parte deles.

\section{NOVAS FORMAS DE CONTRATA- ÇÃO E DEMISSÃO}

Nesta parte, trataremos de formas de contratação que foram introduzidas antes da Reforma - como o contrato por prazo determinado e por tempo parcial - ou a partir desta como o contrato intermitente e a demissão por acordo -, as quais têm em comum o fato de introduzirem variações no padrão de emprego historicamente instituído pela CLT - o contrato por tempo indeterminado, em tempo integral, com jornadas previamente determinadas. As modalidades escolhidas para esta análise são aquelas disponíveis no CAGED. Por essa razão, não serão consideradas outras formas de contratação, a exemplo do teletrabalho e do trabalho autônomo exclusivo.

Antes, de modo a melhor posicionar o Nordeste nesse contexto mais amplo, observaremos tendências recentes do mercado de trabalho no país e nas Grandes Regiões. Para isso, utilizaremos dados da PNAD Contínua. A primeira delas se refere à taxa de desocupação, entre os últimos quadrimestres de 2014 a 2018 (Gráfico 1). Todas as regiões registram um movimento similar, vindo de patamares inferiores em 2014, apresentando crescimento em 2015 e 2016, quando atingem um pico e, em seguida, se comportam com variações para cima ou para baixo, mas, em geral, mantendo-se nesse patamar. O contraste maior se observa entre as regiões Nordeste e Sul, com as mais altas e mais baixas taxas, respectivamente. A primeira passa de $8,3 \%$ (2014) para 14,4\% (2016), oscilando menos de um 1,0\% para baixo (2017) e voltando ao mesmo patamar (2018). Ao final, quase duplica a taxa de desocupação. A segunda parte de uma taxa bem mais baixa $(3,8 \%)$ vai a 7,7\% (2016) e, em seguida, cai, chegando a 7,3\% (2018). Embora quase dobrando a taxa 
inicial, termina em um patamar inferior ao iniciado pelo Nordeste. sempre o Nordeste e o Norte, enquanto as demais regióes se posicionam abaixo.

A questão que nos interessa Gráfico 1 - Taxas de desocupação da força de trabalho, na semana de
referência, das pessoas de 14 anos ou mais de idade $-4^{\circ}$ Quadrimestre
de 2014 ao $4^{\circ}$ Quadrimestre de 2018

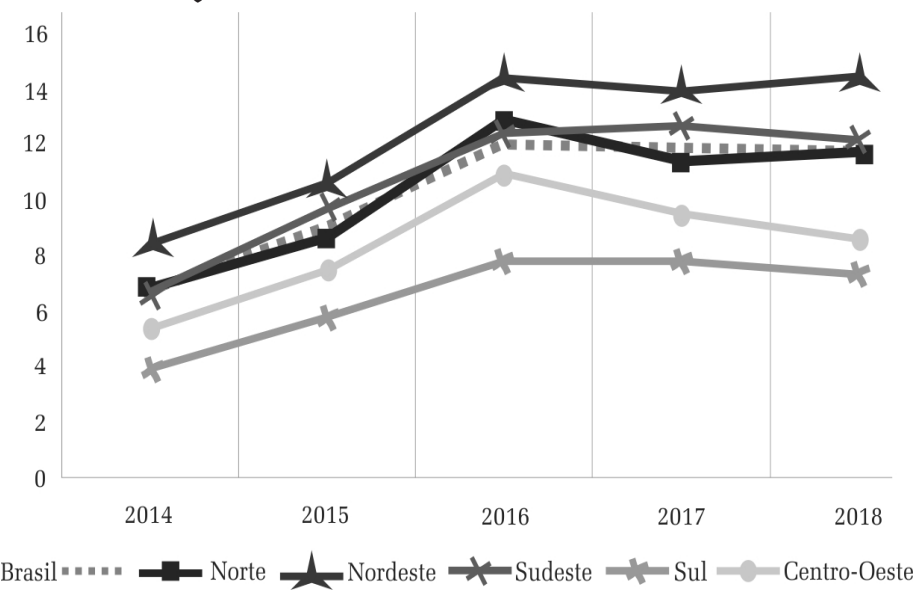

Fonte: Elaborado pelos autores, com base no IBGE/PNAD (2019).

Também vale considerar, aqui, a taxa de subutilização da força de trabalho. ${ }^{4}$ Em comparação com o anterior, este é um indicador mais preciso sobre as reais condições do mercado de trabalho. Novamente se evidencia o contraste entre o Nordeste (com as taxas mais elevadas) e o Sul (mais baixas), com a primeira passando de 24,0\% (2014) para 35,7\% (2018), e a segunda, de $8,6 \%$ para $14,0 \%$, nos mesmos anos. Acima das taxas para o Brasil se mantêm

Gráfico 2 - Taxas de subutilização da força de trabalho, na semana de referência, das pessoas de 14 anos ou mais de idade $-4^{\circ}$ Quadrimestre de 2014 ao $4^{\circ}$ Quadrimestre de 2018

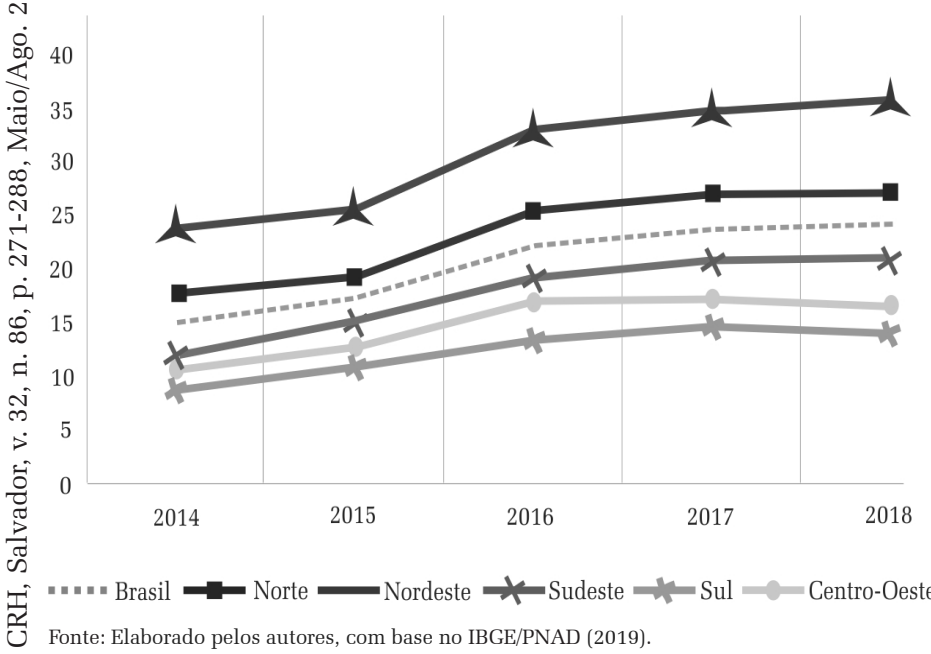
trabalhadas, os desocupados e a força de trabalho potencial. destacar aqui é discutir como repercutem os efeitos da Reforma Trabalhista sobre o Nordeste. Trata-se de uma Região que, historicamente, apresenta condições mais desfavoráveis no mercado de trabalho, em comparação com o conjunto do país e, em especial, com o Centro-Sul, e que vem sofrendo mais fortemente (conforme foi indicado acima) os efeitos da crise econômica nacional desencadeada a partir de 2015.

Com base nos dados do CAGED, de agosto de 2016 a outubro de 2017 (14 meses antes de a Reforma entrar em vigência) e de novembro de 2017 a janeiro de 2019 (14 meses após sua entrada em vigência), enquanto, no caso do Brasil, o percentual médio de admissões por prazo determinado (sobre o conjunto de todas as admissões com carteira assinada) passou de $4,9 \%$ para $5,5 \%$, no Nordeste, as respectivas proporções foram maiores em ambos os períodos, passando de 7,0\% para 7,5\%. Ou seja, apesar da Reforma, continuam prevalecendo amplamente, no país e na Região, os contratos formais por prazo indeterminado, os quais são, como atesta ampla bibliografia, historicamente flexíveis no Brasil e, mais ainda, no Nordeste (onde prevalecem farta disponibilidade de força de trabalho e altas taxas de rotatividade no emprego). Apesar disso, a partir da implementação da Reforma, tanto no país como na Região, houve elevação no percentual de contratação por prazo determinado (mesmo não tendo sido essa modalidade uma inovação da nova lei), o que indica, também por essa via, influência da Reforma na precarização do trabalho em ambos os casos.

Com o Gráfico 3 se observa que a inci- 
dência de admissões por prazo determinado, na Região, se manteve sempre, antes e depois da implementação da Reforma, acima dos patamares do Brasil, sendo que, nos últimos meses, se verifica um movimento de convergência, até atingir o mesmo percentual no último mês da série.

Gráfico 3 - Participação do Contrato de Trabalho Prazo Determinado no Nordeste e Brasil - jan/2017 a jan/2019

12,0

10,0

8,0

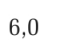

4,0

4

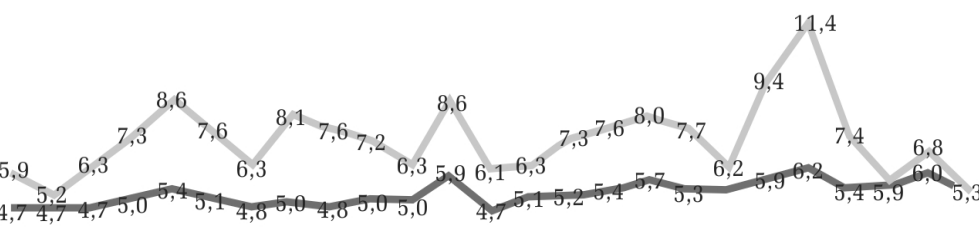

2,0

0,0

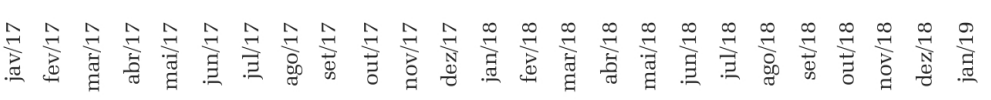

-Brasil Nordeste

Fonte: Elaborado pelos autores, com base no CAGED (2019).

Nota-se, nos dados do Quadro 1, que a te (6,9\%). No caso da construção civil na Paraíproporção de contratos por prazo determinado ba, ${ }^{7}$ ela manteve uma posição intermediária na

Quadro 1 - Principais Atividades com Contrato de Trabalho Prazo Determinado no Nordeste, no Sudeste e no Brasil - jan/2017 a jan/2019

\begin{tabular}{|c|c|c|c|}
\hline \multicolumn{2}{|l|}{ Brasil } & \multicolumn{2}{|l|}{ Nordeste } \\
\hline Atividades & $\begin{array}{l}\text { \% dos } \\
\text { CPD }\end{array}$ & Atividades & $\begin{array}{c}\% \text { dos } \\
\text { CPD }\end{array}$ \\
\hline Comércio Varejista de Artigos do Vestuário e Acessórios & 3,9 & Fabricação de Açúcar em Bruto & 8,8 \\
\hline Locação de Mão-De-Obra Temporária & 3,6 & Cultivo de Uva & 6,1 \\
\hline $\begin{array}{l}\text { Comércio Varejista de Mercadorias em Geral, com Predominância de } \\
\text { Produtos Alimentícios - Hipermercados e Supermercados }\end{array}$ & 2,8 & Cultivo de Cana-De-Açúcar & 4,4 \\
\hline Atividades de Atendimento Hospitalar & 2,5 & Construção de Edifícios & 4,4 \\
\hline Construção de Edifícios & 2,5 & $\begin{array}{l}\text { Comércio Varejista de Artigos do Vestuário e } \\
\text { Acessórios }\end{array}$ & 4,0 \\
\hline Produção de Sementes Certificadas & 2,3 & Atividades de Atendimento Hospitalar & 3,5 \\
\hline Atividades de Associações de Defesa de Direitos Sociais & 2,3 & Fabricação de álcool & 2,7 \\
\hline Cultivo de Café & 2,2 & Locação de Mão-De-Obra Temporária & 2,1 \\
\hline Montagem de Instalações Industriais e de Estruturas Metálicas & 2,1 & $\begin{array}{l}\text { Atividades de Ensino não Especificadas } \\
\text { Anteriormente }\end{array}$ & 1,9 \\
\hline Fabricação de Açúcar em Bruto & 2,0 & Cultivo de Café & 1,6 \\
\hline
\end{tabular}

Fonte: Elaborado pelos autores, com base no CAGED (2019).

varia entre diferentes atividades, em se tratando de Brasil e Nordeste. Enquanto, no primeiro caso, ganham destaque atividades comerciais e de serviços, seguidas de construção civil e agroindústria, no Nordeste a agroindústria da cana e da uva projetam-se para a primeira posi- comparação com os demais e equivalente ao patamar nacional para o setor $(3,0 \%)$.

${ }^{5}$ Usamos como filtro, na base de dados do CAGED, os códigos da CNAE 620 e 631 (Classes).

${ }^{6}$ Usamos o código da CNAE 29 (Divisão).

${ }^{7}$ Usamos o código da CNAE F (Seção). 
Gráfico 4 - Participação do Contrato Trabalho Prazo Determinado no Nordeste e Brasil para atividades selecionadas - jan/2017 a jan/2019

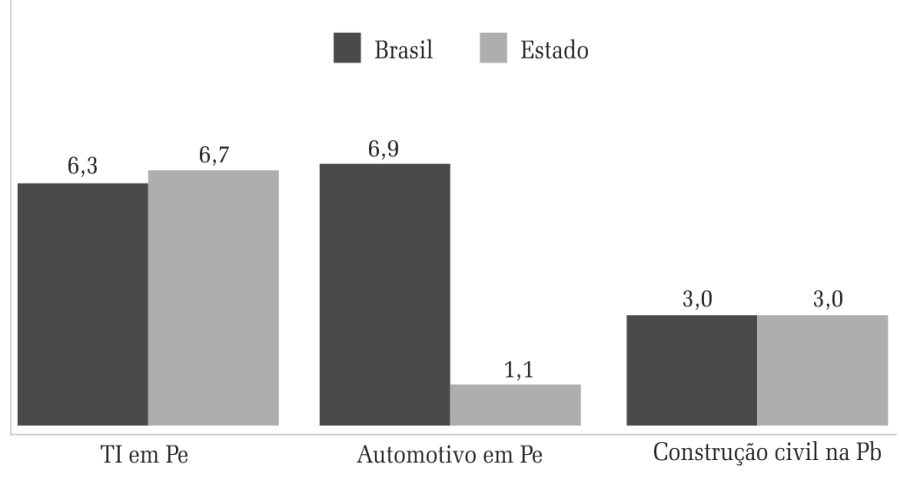

Fonte: Elaborado pelos autores, com base no CAGED (2019).

Passemos à análise da incidência do contrato de trabalho intermitente, uma novidade trazida pela Reforma Trabalhista. Trata-se de uma modalidade que amplia a liberdade de os empregadores utilizarem a força de trabalho de acordo com suas conveniências, ao mesmo tempo em que restringe o poder de os trabalhadores planejarem sua vida pessoal e de sua família. Considere-se, ainda, que a contratação sob tal modalidade não implica que o contratado será necessariamente acionado para o trabalho, podendo não sê-lo em nenhum momento da semana ou do mês, ao que não gará jus a qualquer remuneraసे. ção. Ou, em sendo por poucas vezes, terá direito a uma remuneração muito baixa. ${ }^{8}$ Para Krein, Gimenez e Santos $\stackrel{\infty}{\sim}$ (2018), o contrato intermitenస te submete o trabalhador a $\therefore$ uma condição de alta instabilidade. ${ }^{9}$

Gráfico 5 - Participação das Admissões de Trabalho Intermitente frente ao total de admitidos, respectivamente no Nordeste e no Brasil- abr/2018 a jan/2019

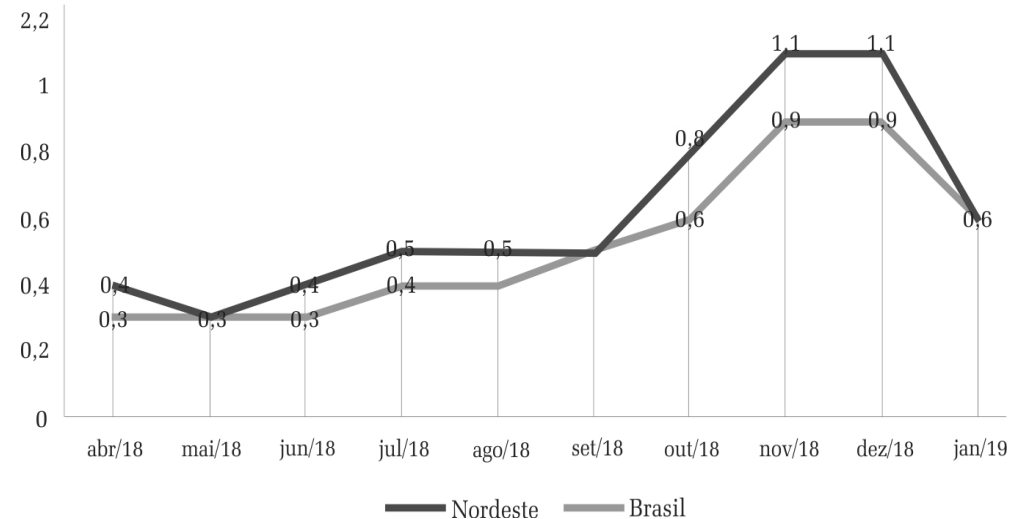

Fonte: Elaborado pelos autores, com base no CAGED (2019).

กิ ${ }^{8}$ Reportagem da Veja, de 27 de outubro de 2017 se refere

$>$ a um anúncio do grupo Sá Cavalcante, prometendo pagar

ثิ R $\$ 4,45$ por hora trabalhada, por jornadas de 5 horas nos

đó sábados e domingos, o que deveria totalizar R\$ 182,00 ao

mês, se o contratado efetivamente viesse a ser convocado

i em todos os finais de semana e em ambos os dias (Reforma..., 2017).

원 ${ }^{9} \mathrm{O}$ contrato de trabalho intermitente, no qual o trabalho é pago por hora trabalhada, sem que haja garantia de um mínimo de horas de trabalho e, consequentemente, de previsão de renda a ser regularmente percebida pelo trabalhador, vem emergindo em várias partes do mundo. Integra o
Segundo os dados do Gráfico 5, a participação relativa dos contratos de trabalho intermitente no total de admitidos manteve-se inexpressiva para o conjunto do país, de abril de 2018 a janeiro de 2019, com tendência de crescimento até dezembro, quando estacionou no mesmo patamar, apresentando queda significativa no mês de janeiro. Será preciso, contudo, continuar observando, daqui para diante, para que se constate se se trata de uma saturação precoce dessa modalidade de contratação. No que concerne ao Nordeste, a região seguiu a mesma evolução do Brasil, mas sempre com uma taxa igual ou superior. Na média, enquanto, para o Brasil, as admissões nessa modalidade atingiram, para o período, $0,5 \%$ do total, no Nordeste, essa proporção foi de $0,6 \%$. Ou seja, até o momento, esse tipo de contrato não avançou significativamente nem no Brasil nem no Nordeste. Este, 
Enquanto para todos os segmentos foram admitidos 0,5\% nessa modalidade, entre abril de 2018 e janeiro de 2019, no que se refere à construção civil, em particular, foram admitidos 0,9\% para o Brasil, 0,5\% para o Nordeste e 0,2\% para a Paraíba. Para o segmento automotivo e o de TI (software) em Pernambuco, não houve registros de contratos nessa modalidade, para o período.

Quanto às admissões na forma de contratos em tempo parcial, conforme mostra o Gráfico 6, a participação relativa do Nordeste foi bem mais expressiva $(30,6 \%)$ do que a da Região no total das admissões de abril de 2018 a janeiro de 2019 (13,7\%).

Gráfico 6 - Distribuição Proporcional dos Admitidos em Geral e em Tempo Parcial por Regióes - abr/2018 a jan/2019

Total de admitidos Trabalho parcial

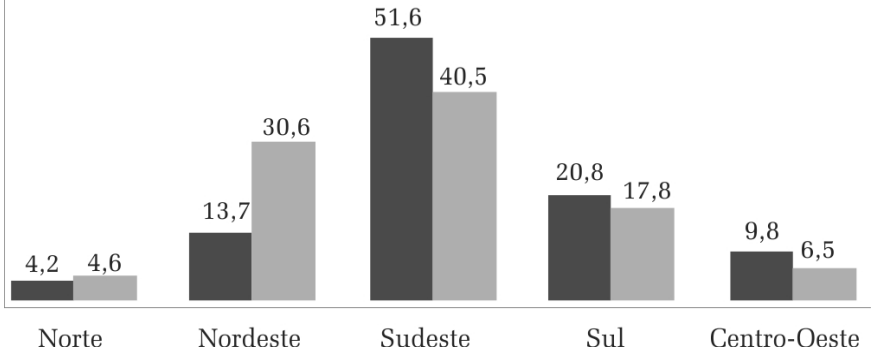

Fonte: Elaborado pelos autores, com base no CAGED (2019)

A maior importância relativa do Nordeste nos contratos de trabalho em tempo parcial fica evidenciada quando comparamos, para a Região e o Brasil, a proporção, em cada caso, dos contratos nessa modalidade em relação aos totais de admitidos em cada caso, entre abril de 2018 e janeiro de 2019: 1,0\% no primeiro caso e $0,4 \%$ no segundo. Observando-se mês a mês (Gráfico 7), nota-se uma incidência relativamente maior na Região, em proporção mais pronunciada do que no caso do trabalho intermitente. Isso ocorre, embora, em ambos os casos, tal incidência se mantenha em níveis baixos e sem clara indicação de que irão passar abr/2018 a jan/2019 a patamares mais elevados no futuro.

No que concerne à construção civil, os contratos em tempo parcial, frente às admissões totais, representaram, no período aqui considerado, $0,1 \%$ no Brasil, $0,2 \%$ no Nordeste e $0,3 \%$ na Paraíba. Já no caso do segmento de TI (software), os percentuais de contratos em tempo parcial foram de $0,5 \%, 2,4 \%$ e 0,7\%, para o Brasil, Nordeste e Pernambuco, respectivamente. Quanto ao setor automotivo, a incidência de contratos por tempo parcial, para o período considerado, esteve entre zero (Pernambuco) e próximo de zero (Nordeste, com 0,06\%, e Brasil, com 0,05\%).

$\mathrm{Na}$ análise dos desligamentos por acordo entre empregados e empregadores, enquanto a participação do Nordeste, no Brasil, chegou a $9,3 \%$, no período considerado, no conjunto dos desligamentos, tal participação alcançou 13,4\%. De todas as situações aqui analisadas, essa foi a única em que o Nordeste apresentou um desempenho inferior ao do Brasil (ver Gráfico 8). Em todos os casos, contudo, os percentuais de ocorrência, embora variados, têm sido mantidos em patamares ainda muito baixos, seja para o país, seja para a Região.

Analisando mês a mês a evolução da frequência desse tipo de desligamento, nota-se (Gráfico 9) que, em todo o período, o Nordeste se manteve abaixo do país.

Gráfico 7 - Participação das Admissões de Trabalho em Tempo Parcial frente ao total de admitidos, respectivamente no Nordeste e no Brasil-

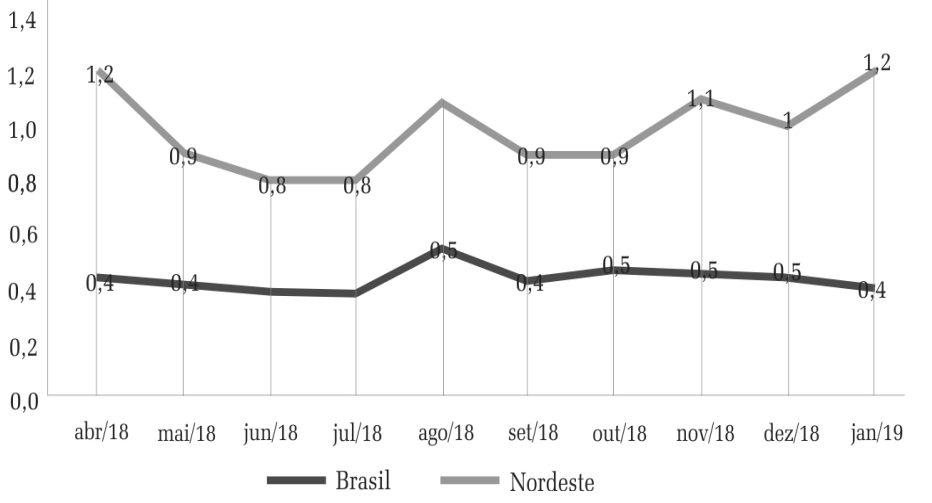

Fonte: Elaborado pelos autores, com base no CAGED (2019). 
Gráfico 8 - Distribuição Proporcional dos Desligamentos em Geral e por Acordo por Regióes - abr/2018 a jan/2019

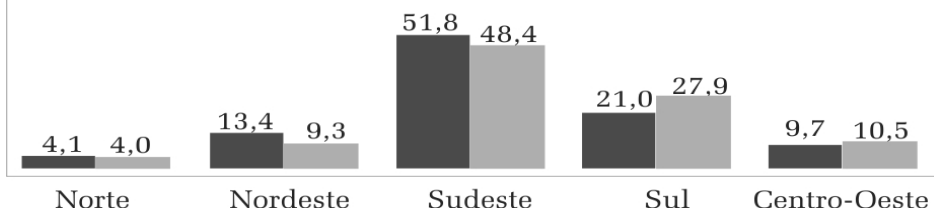

Fonte: Elaborado pelos autores, com base no CAGED (2019).

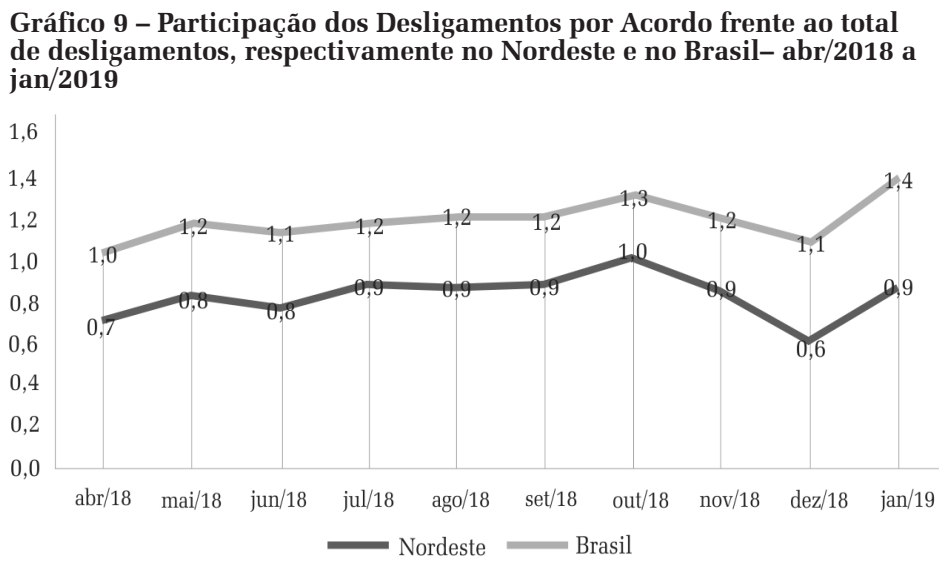

Fonte: Elaborado pelos autores, com base no CAGED (2019).

No caso específico da construção civil, temos que, enquanto, para o Brasil, o percentual de desligamentos por acordo representou $0,7 \%$ do total de desligamentos do período $\stackrel{2}{\overrightarrow{2}}$ considerado, para o Nordeste, esse percentuণ al foi de 0,5\% e, para a Paraíba, de 0,3\%. Para

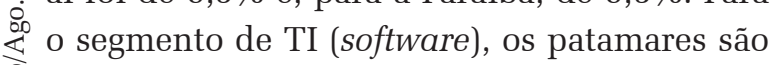
mais elevados, sendo de 1,7\% para o Brasil, de 1,2\% para o Nordeste e de 1,9\% para Pernam$\stackrel{\infty}{N}$ buco. No setor automotivo, os patamares se N aproximam mais dos da construção civil, seni. do maior no Brasil (0,9\%) do que no Nordeste $\stackrel{\not}{\not}(0,3 \%)$ e em Pernambuco $(0,2 \%)$.

ले Comparando-se o Nordeste com o Brasil, pode-se dizer, a partir dos dados analisados, que as novas modalidades de contrato, por prazo determinado, intermitente e em tempo parcial (que, se não foram criados pela Reforma Trabalhista, são estimulados por ela) vêm tendo uma incidência relativamente maior no Nordeste e, dessa maneira, contri- buem para reforçar (embora ainda tangencialmente) os efeitos da atual crise econômica, no sentido do agravamento das desigualdades sociais e regionais no país por meio da precarização das relações de trabalho. Também os desligamentos por acordo contribuem para piorar a situação dos trabalhadores nordestinos, embora, excepcionalmente, sua incidência, na Região, venha se mantendo em patamar inferior ao do país. Sobre os segmentos estudados, em geral, eles se mantiveram em patamares inferiores em relação às respectivas médias nacionais e regionais. Provavelmente, uma das razões para isso se refere à atuação sindical.

\section{NOVOS DESAFIOS DAS NEGOCIAÇÕES COLETIVAS}

Na tramitação do Projeto de Lei da Reforma Trabalhista no Congresso, José Pastore, economista da FGV-RJ, a avalizou nos seguintes termos:

Transformado em lei, o projeto 6.787/2016 estimulará ainda mais a prática da negociação coletiva. Nessa trajetória, a nova lei levará empregados e empregadores a ficarem vigilantes em relação aos seus sindicatos o que, em última análise, ajudará a melhorar a sua representatividade (Pastore, 2017).

Estudo do DIEESE (2018), contudo, com base nos dados do Sistema Mediador do extinto Ministério do Trabalho, constatou que as mudanças trazidas com a Reforma repercutiram negativamente sobre as negociações coletivas. Conforme mostra o Gráfico 10, houve queda em todos os meses, na variação mensal dos registros de acordos e convenções coletivas, comparando-se os anos de 2017 e 2018, de janeiro a outubro. 
Gráfico 10 - Variação mensal dos registros de acordos e convenções coletivas no Mediador em 2018 (sobre igual mês de 2017)

Acordos Lioletivos

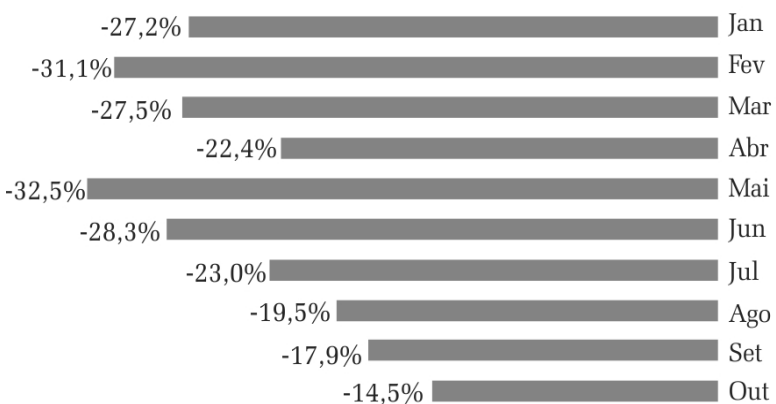

Lonvençoes Loletıvas

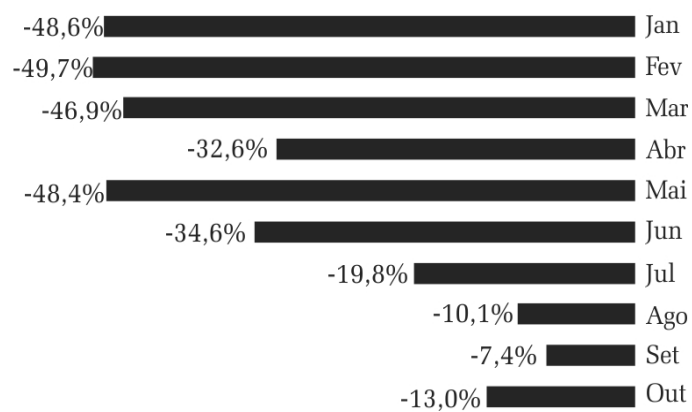

Fonte: Elaborado pelos autores, com base no Ministério do Trabalho/ Sistema Mediador (2019).

Clovis Scherer (2018), economista e técnico do DIEESE, apresenta três hipóteses explicativas para a queda nas negociações coletivas, durante o período considerado:

O primeiro deles seria a falta de conhecimento das regras da reforma pelos agentes da negociação, o que pode ser relacionado ao fato de que a lei teve tramitação muito rápida e com pouco debate na sociedade. A segunda hipótese é a de que, entre 14 de novembro de 2017 e 23 de abril de 2018, vigorou a Medida Provisória (MP) 808/2017, que alterava alguns pontos da reforma. Ainda que a MP não tivesse como foco principal a negociação coletiva, salvo em alguns itens pontuais, a insegurança sobre sua conversão em lei (que acabou não acontecendo) pode ter gerado uma atitude de cautela por parte de muitos negociadores. O terceiro fator seria a existência de divergências de interpretação da lei quanto à possibilidade de fixação de contribuição sindical ou de contribuição assistencial em convenção ou acordo, o que teria dificultado o consenso entre as partes.

O fato, no entanto, é que não fechar um acordo tem se caracterizado, eventualmente, como estratégia sindical no sentido de preservar direitos dos trabalhadores. Com a Reforma Trabalhista e um ambiente político favorável, os empregadores estão mais à vontade para avançar em sua agenda de subtração de direitos também nos momentos de negociações coletivas.

Para o DIEESE (2018), alguns itens da Reforma Trabalhista vêm sendo mais frequentemente pautados pelos empregadores nas negociações coletivas, conforme mostra a Tabela a seguir.
Tabela 1 - Itens da pauta patronal que entraram no acordo final, 2018

\begin{tabular}{l|c|c}
\hline Cláusulas & $\mathbf{N}^{\mathbf{0}}$ & $\%$ \\
\hline Fim da homologação das rescisões no sindicato & 15 & 19,0 \\
\hline Estabelecimento da jornada 12hx36hs & 12 & 15,2 \\
\hline Parcelamento das férias em 3 vezes & 12 & 15,2 \\
\hline $\begin{array}{l}\text { Acordo individual para o Banco de horas / compensa- } \\
\text { çào da jornada }\end{array}$ & 11 & 13,9 \\
\hline Prevalência do negociado sobre o legislado & 5 & 6,3 \\
\hline Outros & 24 & 30,4 \\
\hline Total & 79 & 100,0 \\
\hline
\end{tabular}

Fonte: Pesquisa "Acompanhamento das negociações coletivas pós reforma trabalhista” (2018).

Elaboração: Subseção DIEESE/CUT Nacional, 2018.

A negociação coletiva não só foi enfraquecida como instrumento de reconhecimento de direitos trabalhistas e sociais, como tem sido acionada pelos empregadores como meio de legitimação das medidas de precarização do trabalho previstas pela Reforma. Vejamos, mais especificamente, o que vem ocorrendo com os processos de negociação coletiva envolvendo o SITRICOM-JP, o SINDPD-PE e o SINDMETAL-PE. Como tem sido possível, sob condições extremamente adversas, resistir à ofensiva patronal?

\section{O SITRICOM-JP, AS INVESTIDAS PATRONAIS E OS IMPASSES NAS NEGOCIAÇÕES}

O SITRICOM-JP firmou sua última Convenção Coletiva de Trabalho (CCT) em 31 de janeiro de 2017, sendo válida até janeiro de 2018. No segundo semestre de 2017, a cam- 
panha salarial transcorreu logo após a aprovação da Reforma e impactou diretamente o ambiente da Negociação Coletiva. O Sindicato da Indústria da Construção Civil de João Pessoa (SINDUSCON-JP), representante dos empregadores locais, exigiu a inclusão, na pauta, do fim da homologação das rescisões no Sindicato, convertendo-se esse quesito no principal elemento do impasse.

Sem solução na mesa, o Sindicato resistiu à pressão patronal e foi a Dissídio no Tribunal Regional do Trabalho (TRT) em março de 2018, o qual, contudo, ainda não foi concluído. Após as eleições presidenciais de outubro, sob uma correlação de forças mais favorável, o setor patronal, com a campanha salarial de 2018 ainda em aberto, propôs que o SITRICOM abrisse mão da reposição da inflação anual (INPC) de 2017. Novo impasse criado.

Como resultado desse processo, acumulam-se mais de dois anos sem um acordo entre as partes, com risco de que os trabalhadores percam cláusulas mais favoráveis do que o que garante a lei atual, como a remuneração adicional de $80 \%$ na hora extra para qualquer dia da semana. A homologação no Sindicato, razão do primeiro impasse na negociação coletiva, foi reduzida para $30 \%$ do que representava antes da Reforma Trabalhista, numa demonstração de $\rightarrow$ que a pauta patronal, pelo menos nesse ponto, em sido vitoriosa na prática, à revelia da CCT.

Enquanto isso, o SITRICOM, como estratégia de resistência, não tem aceitado uma - CCT com perdas consideradas inaceitáveis, seguindo na mobilização da categoria para ter, ลิ retroativamente, a reposição acumulada de : $5,5 \%$ de inflação, mesmo correndo o risco de

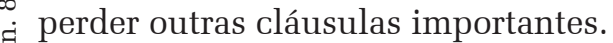

\section{Negociação e conquistas na FCA}

A fábrica da FCA e seus fornecedores, denominados sistemistas, entraram em operação em abril de 2015. Desde então o SINDMETAL-PE vem firmando Acordos Coletivos de
Trabalho (ACT) específicos para o Polo Automotivo de Goiana.

Segundo o presidente do Sindicato, tais ACT são ligeiramente superiores às CCT da categoria metalúrgica no Estado, mas as condições de trabalho do Polo Automotivo de Goiana estão entre as mais precárias, quando comparadas às do setor automobilístico nacional. Por exemplo, em 2016, não havia pagamento de PLR na fábrica da FCA, enquanto os trabalhadores das plantas da Fiat em Campo Largo (PR) e em Betim (MG) já haviam recebido R\$ 4.500 e R\$ 4.737, respectivamente. A PLR, no Polo Automotivo de Goiana, foi conquistada no ACT de 2017/2018, no valor de R\$2.854. Em 2018/2019, o valor máximo de PLR, a depender do percentual de cumprimento de metas, pode chegar a R\$ 3.150. Esse valor corresponde a $60 \%$ do acordo feito em Betim, razão pela qual, em Minas Gerais, a empresa chantageia o Sindicato local: "Se apertar muito, nós mandamos [a produção] para Pernambuco!"10 Mesmo abaixo dos patamares médios do setor automobilístico nacional, tal valor está acima do PLR de outras empresas da base metalúrgica em Pernambuco.

Outras conquistas, no ACT 2018/2019, foram: ampliação de três produtos na cesta básica; desconto de 50\% com farmácia para o trabalhador do Polo; campanha odontológica para os trabalhadores e seus dependentes; estabilidade para o pré-aposentado; e incorporação de áreas de descanso dentro da empresa. Nas cláusulas econômicas, houve reajuste de $5 \%$ no piso inicial, $4,5 \%$ no piso do profissional e em torno de $4 \%$ de reajuste para todos que recebem acima do piso. ${ }^{11}$

A pressão, na Mesa de Negociações, esteve concentrada no rebaixamento dos valores e dos direitos, sob o argumento de que as sistemistas não poderiam pagar o mesmo que a Jeep. Ao que tudo indica, há, contudo, uma pressão da

${ }^{10}$ Fala do presidente do SindMetal na Assembleia de encerramento da campanha salarial da categoria.

${ }^{11}$ Em 2016, o piso de ajudante, na Jeep, era de $\mathrm{R} \$ 1.057,00$; em 2017, foi para $\mathrm{R} \$ 1.191,00$; e, em 2018, para $\mathrm{R} \$$ $1.290,00$. Valores pouco acima do supply park (informação verbal). 
própria Jeep para uma uniformização "por baixo". Segundo o presidente do SINDMETAL, dirigentes de empresas do supply park o procuraram "em off”, para informar que poderiam melhorar a proposta das cláusulas sociais, não fosse a orientação da Jeep de endurecer as negociações.

A maior dificuldade encontrada pelo SINDMETAL-PE, no Polo Automotivo de Goiana, tem sido a prática antissindical desempenhada por empresas que, segundo sindicalistas, perseguem aqueles trabalhadores que se aproximam das lideranças sindicais, ou que simplesmente aceitam receber o Boletim do Sindicato. As assembleias de campanha salarial, dizem eles, contam com a participação de muitos prepostos da empresa, que exercem vigilância no dia a dia da fábrica. $\mathrm{O}$ resultado é que, em todo o Polo de Goiana, dentre os mais de 9.000 trabalhadores entre Jeep e sistemistas, há, até o momento, apenas quatro trabalhadores sindicalizados, depois de cinco anos de funcionamento. $\mathrm{O}$ dirigente sindical entrevistado informou ter evitado realizar atividades de sindicalização, com receio de expor seus colegas à retaliação. O SINDMETAL chegou a abrir uma sede em Goiana, mas ela teve pouco tempo de funcionamento devido à pouca presença de trabalhadores no dia a dia.

Quanto à pressão patronal para incutir aspectos da Reforma Trabalhista nos instrumentos normativos, o presidente do SINDMETAL-PE realizou um breve balanço na Assembleia de encerramento da Campanha Salarial e de aprovação do ACT 2018/2019:

A lei [Reforma Trabalhista] formaliza que pode ter meia hora de almoço [...] Eles podem aplicar meia hora de refeição. Mas só podem fazer após uma Assembleia com todos os trabalhadores. Só que, no Polo Automotivo, eles não querem o Sindicato lá dentro. Por isso que eles recuaram! É a mesma coisa da gestante lactante... O 12x36 as empresas queriam implementar em vários postos de trabalho, mas a gente também não cedeu [...] A questão da parada técnica, ela é um Banco de Horas, de fato. A reforma trabalhista condicionou que pode fazer o Banco de Horas com acordo com o Sindicato ou com acordo individual. O que aconteceu? A partir do momento que a gente começou a travar tanto a Jeep como o supply, [a empresa] começou a mandar cada trabalhador individualmente aceitar a parada técnica. Para não comprometer a PLR - e [considerando que] a lei já dá poder para as empresas aplicarem o Banco de Horas -, a gente não ia se desgastar por uma questão dessa. Existe abuso? Existe. A empresa faz quando quer, em geral? Sim. Mas a gente só vai conseguir [barrar] com nossa força; vai conseguir isso quando a gente tiver mais organizado... A gente não tem Banco de Horas no setor metalúrgico em Pernambuco, a não ser no Polo, devido à organização no chão da fábrica. Mesmo com a reforma trabalhista...

A dinâmica de negociação no Polo Automotivo de Goiana reflete mais a dificuldade de o Sindicato dos Metalúrgicos superar a prática antissindical das empresas e legitimar-se politicamente junto aos trabalhadores, do que, propriamente, devido às medidas da Reforma Trabalhista, exceção feita ao tema do acordo individual de Banco de Horas, conforme indica a fala acima.

\section{Estratégia patronal e a resistência do SIN- DPD-PE}

A campanha salarial de 2017 do SINDPD-PE, com data-base em setembro, ocorreu em paralelo à tramitação da Reforma. No ano seguinte, com a nova lei já em vigência, a representação empresarial substituiu seu principal assessor nas mesas de negociação, com o intuito de promover a introdução de itens da Reforma Trabalhista na pauta. A pressão empresarial visou, sobretudo, à implantação do Banco de Horas individual - ou seja, sem acordo com o Sindicato -, a redução no valor da Hora Extra, a retirada do Sindicato como mediador da homologação das rescisões dos contratos de trabalho, entre outras medidas.

A estratégia, no entanto, se mostrou malsucedida. Parte do patronato mais antigo divergiu da posição adotada na negociação e optou por manter as relações sindicais como vinham ocorrendo nos anos anteriores, o que implicou o retorno do antigo assessor à mesa de negociação. Ao mesmo tempo, o Sindicato 
conseguiu se impor mais fortemente nas negociações. Os trabalhadores compareceram às assembleias, embora não em massa, mas em proporção maior do que na campanha salarial de 2017. Com isso, foi mantida a maior parte das conquistas anteriores, ocorrendo alterações pontuais, incluindo a introdução de novas conquistas, como o aumento da licença-paternidade e do número de dias de abono para acompanhar filhos e (ou) cônjuge ao médico.

Em um balanço geral sobre as três categorias aqui consideradas, é possível dizer que houve um aumento da pressão empresarial no sentido de ratificar as medidas da Reforma Trabalhista e de promover a retirada de direitos. No entanto, também é possível constatar sinais de alguma reação sindical, por meio de estratégias diversificadas para evitar perdas e, em situações pontuais, promover ganhos. Contudo, como veremos a seguir, a Reforma visou, também, a fragilizar os sindicatos.

\section{O SINDICALISMO, LÓCUS ES- TRATÉGICO DE RESISTÊNCIA, É ALVO PRIORITÁRIO DE ATAQUES}

Próximo de um ano de vigência da nova legislação laboral, a Rede de Estudos e Moni$\stackrel{2}{*}$ toramento Interdisciplinar da Reforma TrabaN lhista (REMIR - Trabalho) realizou entrevistas $\stackrel{\circ}{\&}$ com 79 sindicatos de todas as regiões do país, de diversos setores de atividade econômica, filiados a distintas centrais sindicais, visando a captar as primeiras impressões sindicais sobre a implementação da Reforma. Seus resulta. dos parciais foram apresentados no Seminário "Um ano de vigência da reforma trabalhista: efeitos e perspectivas", realizado em Brasília, em parceria com o Ministério Público do Trabalho, em novembro de 2018.

As entrevistas serão analisadas buscando-se comparar as respostas fornecidas pelos dirigentes sindicais em geral ${ }^{12}$ e aquelas formu-

${ }^{12}$ Mesmo sem observar representatividade estatística, as respostas aos questionários podem ser tomadas como ex- ladas pelas lideranças do SINTRICOM-JP, do SINDPD-PE e do SINDMETAL-PE. Serão priorizadas as respostas aos itens que tratam dos impactos da Reforma sobre a ação, a organização e o financiamento sindical. Ao tratarmos do caso do sindicato do setor da construção, foram utilizados, de forma tangencial, dados obtidos por meio de 46 questionários aplicados em agosto de 2018, durante o congresso da Confederação Nacional dos Sindicatos de Trabalhadores da Construção e da Madeira (CONTICOM-CUT), à qual o SINTRICOM é filiado.

Em primeiro lugar, no que diz respeito à posição dos sindicatos quanto à implementação da Reforma Trabalhista, 92\% afirmaram ser contrários a ela, defendendo sua revogação completa. No mesmo sentido, 90\% declararam não considerar nenhum aspecto positivo na Reforma, enquanto 10\% afirmaram que ela poderia ser favorável aos trabalhadores nos seguintes aspectos: (a) ao possibilitar a conquista de benefícios, em razão da prevalência do negociado em normas coletivas sobre o que prevê a legislação; (b) ao acabar com a obrigatoriedade do recolhimento do imposto sindical e, assim, com a dependência financeira dele decorrente; (c) ao possibilitar o parcelamento de férias.

Nesse quesito, os dirigentes do SINTRICOM-JP, SINDPD-PE e SINDMETAL-PE afirmaram não perceber nenhum aspecto positivo na Reforma, salientando a existência de inúmeras cláusulas maléficas aos trabalhadores: (a) fim da obrigatoriedade da assistência sindical no ato de homologação das rescisões contratuais, independentemente do tempo de duração do contrato de trabalho; (b) implementação do trabalho intermitente; (c) fim da compulsoriedade de recolhimento do imposto sindical, sem qualquer medida de transição; (d) parcelamento das férias; (e) alterações no banco de horas, no trabalho de gestantes e lactantes em atividades insalubres, entre outras.

Outro tema tratado refere-se ao fim da

pressivas das tendências gerais dos impactos, percepções e reações dos sindicatos frente à Reforma Trabalhista. 
obrigatoriedade de os sindicatos prestarem assistência, no ato de homologação, das rescisões contratuais de trabalhadores com mais de um ano de serviço. Tal medida atingiu duplamente trabalhadores e sindicatos, por reduzir substancialmente as chances de o empregado identificar erros na apuração do valor das verbas rescisórias, bem como por dificultar a detecção de burlas à legislação e diminuir as oportunidades de vínculo entre trabalhadores e sindicatos.

A esse respeito, quase $60 \%$ dos entrevistados constataram a redução do número de homologações realizadas perante o sindicato. Tal redução se confirmou como tendência para os três sindicatos aqui analisados. O SINTRICOM-JP apontou um decréscimo de 70\% no número de homologações (enquanto que, no congresso da CONTICOM, esse índice foi de 93\%). Quanto ao SINDPD-PE e SINDMETAL-PE, ambos afirmaram experimentar uma redução de cerca de 50\% no número de homologações.

Contudo, o aspecto da Reforma que mais diretamente atingiu os sindicatos foi $o$ financiamento sindical. O pagamento de toda forma de contribuição sindical passou a ser condicionada à autorização prévia e expressa dos trabalhadores, extinguindo seu caráter compulsório. Mais recentemente, em março deste ano, o Governo foi mais longe e proibiu por Medida Provisória ( ${ }^{\circ}$ 873) o recolhimento da contribuição sindical por meio de desconto automático em folha de pagamento. ${ }^{13}$ Diante disso, os sindicatos passaram a depender fundamentalmente das mensalidades pagas por associados e da taxa negocial, fontes essas vinculadas, respectivamente, ao crescimento do número de associados e ao êxito nos acordos e convenções coletivas.

No caso do SINTRICOM-JP, observa-se que a ordem de importância conferida aos

${ }^{13}$ Segundo a MP, as contribuições facultativas ou as mensalidades devidas ao sindicato, a exemplo do imposto sindical, só poderão ser recolhidas por meio de boleto bancário ou equivalente eletrônico, o que significa que, mesmo com autorização expressa do trabalhador, o valor correspondente não poderá ser descontado diretamente na folha de pagamento. mecanismos de financiamento se diferencia daquela empregada pelos sindicatos de outras regióes do país, pelo fato de contar, mesmo antes da implementação da Reforma, com a mensalidade de associados como fonte principal, seguida da taxa negocial e, só em terceiro lugar, do imposto sindical. Após a Reforma, esse último perdeu ainda mais importância, reduzindo-se a menos de $20 \%$ do valor recebido anteriormente. No caso do SINDPD-PE, a sustentação financeira era baseada, em ordem de importância, no imposto sindical, na mensalidade dos associados e na taxa negocial. Após a Reforma, o financiamento da entidade passou a ter como fontes principais a mensalidade e a taxa negocial, enquanto o recolhimento do imposto sindical foi reduzido a cerca de $2 \%$ do valor anterior. Já o SINDMETAL-PE tinha como fonte de financiamento, em ordem de importância, o imposto sindical, a taxa negocial e a mensalidade. Após a Reforma, o financiamento do Sindicato passou a depender muito mais da taxa negocial e de fontes derivadas das negociações, onde se destaca o percentual descontado da PLR da FCA. Segundo um dirigente do SINDMETAL que atua no Polo Automotivo, o recolhimento de um valor fixo de $\mathrm{R} \$ 150$ da quantia recebida como PLR de cada trabalhador em favor do Sindicato corresponde, atualmente, a $70 \%$ da receita total da entidade.

Para compensar a perda da arrecadação sindical, as principais iniciativas adotadas pelos sindicatos, dentre várias listadas por cada entrevistado, foram: campanhas de sindicalização de trabalhadores, que visavam a aumentar as contribuições por meio de mensalidades (citadas por $75 \%$ dos sindicalistas); a inclusão das taxas de negociação em convenções coletivas (assinaladas por 37\%); ajuizamento de ações buscando obter decisões judiciais que garantissem a manutenção de mecanismos de financiamento (indicadas por 14\%). Tais iniciativas foram adotadas de modo semelhante pelo SINDPD-PE E SINDMETAL-PE, ao contrário do SINTRICOM-JP, que não buscou incluir novas taxas de negociação na convenção coletiva. 
Se, com a entrada em vigor da Reforma Trabalhista, a arrecadação do imposto sindical se viu dificultada, obrigando os sindicatos a buscarem novas estratégias e fontes de financiamento para manutenção de sua estrutura e de suas atividades, o recente advento da MP 873/2019 trouxe ainda maiores desafios ao custeio das entidades sindicais, prejudicando até mesmo as medidas alternativas que vinham sendo adotadas.

No que diz respeito às principais estratégias sindicais adotadas para enfrentar a Reforma, as respostas obtidas mencionaram tanto ações políticas quanto administrativas, não havendo um padrão de diferenciação significativo entre os sindicatos considerados no âmbito nacional e aqueles selecionados para este estudo. Os dados relativos ao conjunto dos sindicatos incluídos na pesquisa indicaram que $67 \%$ das entidades buscaram adequar a estrutura do sindicato à nova realidade financeira e política. Na mesma proporção, $60 \%$ das organizações informaram adotar, como estratégias, a elaboração de denúncias e a recusa à negociação quanto a qualquer um dos itens da Reforma. Para se adaptarem ao novo contexto, $50 \%$ dos sindicatos informaram que estavam em processo de reestruturação dos serviços oferecidos; 19\% afirmaram defender que os $\rightarrow$ ganhos das negociações coletivas passassem i. a valer somente para os trabalhadores associados; 11\% disseram continuar apostando na derrogação da Reforma, relatando não estarem realizando ajustes organizativos internos.

Quando perguntados sobre "Quais as medidas internas que estão sendo adotadas para se adequar à nova realidade?”, os entrevistados apontaram, entre várias opções, a redução do staff sindical e de custos administrativos diversos, além da venda de patrimônio da entidade (ver Tabela 2). Os três sindicatos considerados neste estudo informaram ter demitido funcionários, enquanto o SINDMETAL-PE também indicou haver reduzido sua diretoria, com o retorno de dirigentes ao local de trabalho.
Tabela 2 - Medidas internas adotadas para se adequar à nova realidade

\begin{tabular}{l|c}
\hline \multicolumn{1}{c|}{ Itens } & $\%$ \\
\hline Demissão de funcionários & 44 \\
\hline Redução de patrimônio [imóveis, frota de veículos] & 24 \\
\hline Fechamento de subsedes & 21 \\
\hline Redução de visitas aos locais de trabalho & 18 \\
\hline Redução de serviços aos associados [saúde, lazer/colônia de férias] & 15 \\
\hline Redução da diretoria/retorno ao local de trabalho & 10 \\
\hline Fechamento de entidades & 1 \\
\hline Outras & 29 \\
\hline
\end{tabular}

Fonte: Pesquisa Sindical - Remir (2018).

Outro item tratado foi o da sindicalização, quando 39\% dos sindicalistas informaram que, após a implementação da Reforma, não houve alteração relevante na quantidade de trabalhadores filiados aos respectivos sindicatos. Outros $23 \%$ observaram uma redução no número de associados, enquanto $16 \%$ indicaram um aumento. Os demais $22 \%$ avaliaram que, apesar de haver alteração no número de trabalhadores filiados a seu sindicato, as causas para a mudança eram de difícil diagnóstico, dado o concomitante aumento do índice de desemprego naquela conjuntura.

Nesse quesito, o SINTRICOM-JP indicou que a sua base de representação contava com cerca de 15.000 trabalhadores, dos quais aproximadamente 6.000 eram sócios do Sindicato (31\%) e estavam com o pagamento das contribuições em dia, ${ }^{14}$ pontuando, ainda, que não observava variação no número de seus associados em razão da implementação da Reforma. O SINDPD-PE informou uma base de representação de 10.000 trabalhadores, com cerca de 1.300 filiados (13\%), tendo apontado uma redução no número de associados, ainda que não tenha sabido afirmar se isso decorreu da Reforma ou da conjuntura econômica. O SINDMETAL-PE afirmou ter 35.000 trabalhadores na sua base de representação, com cerca de 6.800 filiados (19\%). Diferentemente do SINTRICOM-JP, que indicou não haver alteração no número de filiados em razão da Reforma, e do

${ }^{14} \mathrm{O}$ sindicato informou que, se fossem considerados todos os trabalhadores filiados, ou seja, aqueles com a mensalidade paga em dia e aqueles inadimplentes, o número total chegaria a 12.000. Nesse caso, o índice de sindicalização seria de $80 \%$. 
SINDPD-PE, que detectou redução dos filiados, mesmo não identificando uma relação disso com a Reforma, o SINDMETAL-PE atestou aumento do número de associados, de 4.600 para 6.800 trabalhadores, em razão de novas estratégias adotadas pela entidade. Contudo, conforme foi informado anteriormente, no que se refere ao Polo Automotivo, o Sindicato não tem conseguido avançar na sindicalização.

O contexto adverso da crise econômica iniciada em 2015 tem produzindo desafios ao mercado de trabalho, que atingiu elevado nível de desocupação. Além disso, a partir do impeachment de Dilma Rousseff, em 2016, inaugurou-se um ambiente político de ataques aos direitos dos trabalhadores e à ação sindical. Contudo o sindicalismo tem dado mostras greves avolumaram-se na esteira das manifestações de junho de 2013 e das dificuldades econômicas que prenunciaram a crise econômica iniciada em 2015. A partir de então, tem sido observado um salto no número de greves, iniciando-se um ciclo que ainda não findou, de lutas defensivas,$^{15}$ voltadas prioritariamente para a preservação de direitos. Note-se (ainda no Gráfico 11) que, no Nordeste, ocorre um incremento no número de greves proporcionalmente maior ao do Sudeste. Se esses números destoavam muito entre as duas regiões nos períodos anteriores, no atual ciclo houve uma convergência. Trata-se de um indicativo de que o sindicalismo, no Brasil e no Nordeste, apesar das dificuldades, reage ao agravamento das perdas de direitos e ao incremento das desigualdades.

\section{Gráfico 11 - Número de greves - Brasil, Nordeste e Sudeste, 1983 a 2018}

2500

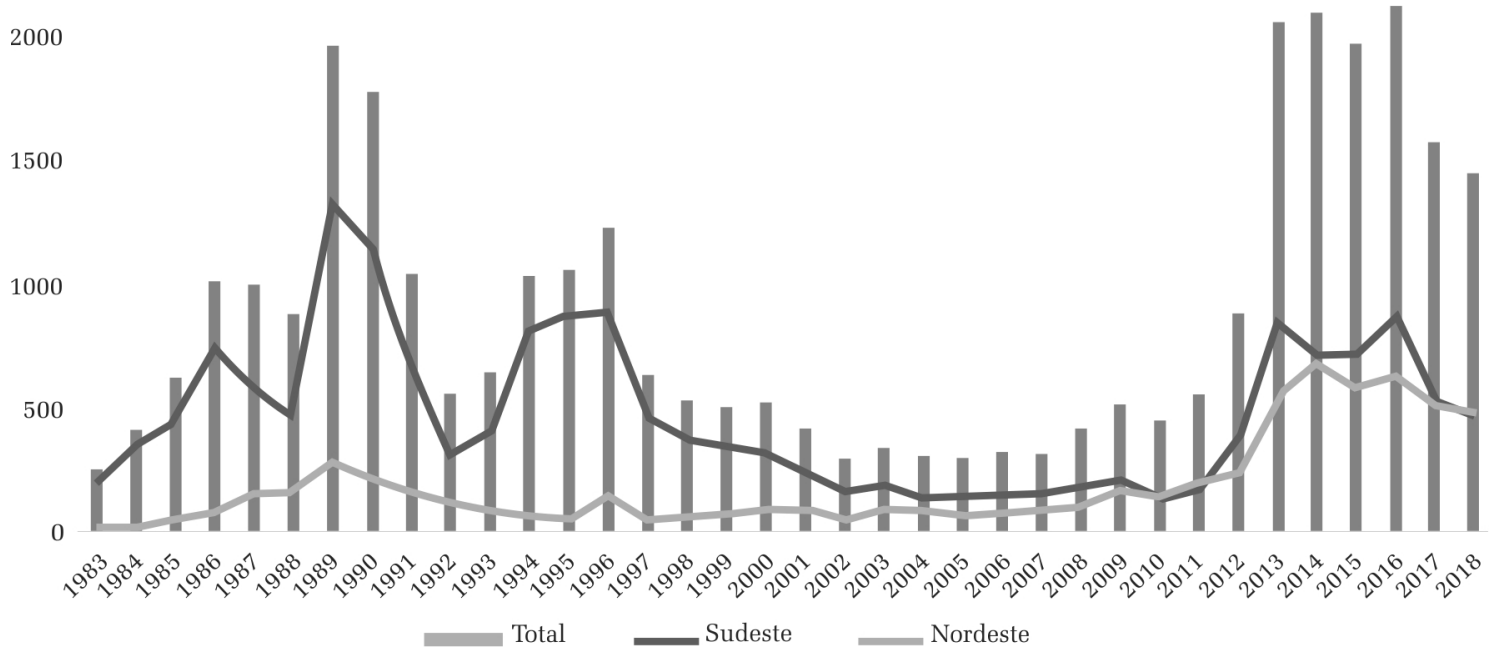

Fonte: Elaborado pelos autores, com base no Sistema de Acompanhamento de Greves - SAG/ DIEESE (2019).

de reação. Um dos indicadores diz respeito ao número de greves. Segundo os dados do Sistema de Acompanhamento de Greves do DIEESE (SAG-DIEESE), de 1983 a 2018, mesmo nos últimos dois anos, mantém-se um volume de greves ainda alto para os padrões históricos expressos na série.

Quando a crise financeira global de 2008/2009 começou a repercutir no país, as

\section{CONSIDERAÇÕES FINAIS}

As implicações da Reforma Trabalhista se somam e se coadunam aos efeitos da crise econômica para compor um cenário desolador para os direitos laborais, acentuando desigualdades históricas experimentadas pelos trabalhadores brasileiros e, com mais contundência, os nordestinos. ${ }^{15}$ No sentido usado por Boito Jr. e Marcelino (2010). 
Desde os anos 1990, contudo, na esteira das políticas neoliberais, paira no ar a chantagem de empresários e governantes sobre o "fim da Era Vargas”, quando se mira, igualmente, os direitos previstos na nova Constituição, responsabilizando os gastos públicos com políticas sociais pela instabilidade econômica do país. A aprovação da Reforma Trabalhista faz parte, portanto, de uma ofensiva política que visa a desconstruir o sistema de proteção social que, com limites, se estabeleceu no país, e a introduzir outro padrão de regulação das relações de trabalho do qual se subtrai o que nele há de público e democrático. Novas modalidades de contrato e de demissão, de teor claramente precarizante, são legalizadas, aproximando o formal do informal. ${ }^{16}$ Novas condições de negociação são previstas, com a primazia do negociado sobre o legislado, sindicatos enfraquecidos e mais espaço para a negociação individual. Os ataques às bases de financiamento dos sindicatos se somam ao esvaziamento da Justiça do Trabalho e à inviabilização do acesso dos trabalhadores aos tribunais.

Os efeitos desse desmonte institucional tendem a repercutir mais fortemente sobre os segmentos mais vulneráveis, o que agrava as desigualdades sociais e regionais (conforme foi indicado na primeira parte deste artigo).

$\rightarrow$ No Nordeste, comparando-se às regiões mais N industrializadas do país, o acesso aos direitos \& trabalhistas se manteve historicamente em patamares mais restritos, com parcelas majoritárias dos trabalhadores relegados à informalidade e à pobreza. Agora, quando o sistema de proteção social, erguido a partir dos anos 1930/1940, sofre severo ataque, suas consequências sobre os trabalhadores nordestinos teni dem a ser mais contundentes.

Há, contudo, conforme vimos aqui, uma situação em disputa, em que o sindicalismo, apesar das adversidades, busca reagir, no Brasil e no Nordeste, seja ao tentar explorar brechas

${ }^{16}$ Esse tem sido um objetivo explícito do novo governo, a exemplo de declaração do presidente no dia 11 de dezembro do ano passado (Soprana, 2018). nas estratégias empresariais de negociação, seja ao ensaiar formas de recompor as bases de financiamento e de organização sindical.

Os três casos focados nesse estudo nos dão a medida da complexidade da situação, quanto aos efeitos da Reforma sobre trabalhadores e sindicatos, assim como quanto às estratégias sindicais de reação a tais efeitos. Em primeiro lugar, é preciso que se levem em conta as consequências combinadas da Reforma e da crise econômica. De outra parte, é fundamental que se observem as diferentes repercussões da Reforma em categorias e regiões diversas.

Alguns aspectos podem ser realçados, quanto a isso, a partir das informações aqui analisadas. Sobre a adoção de novas formas de contratação e demissão, observamos que, enquanto para os setores da construção civil de João Pessoa e do Polo Automotivo de Goiana, a incidência de contrato por prazo determinado, intermitente, em tempo parcial e de demissão por acordo vem se mantendo em níveis insignificantes e bem abaixo dos respectivos padrões nacionais, no segmento de TI de Pernambuco, tal incidência se mostrou mais expressiva (exceção feita ao contrato intermitente), mesmo sendo esse um segmento diferenciado da média do mercado de trabalho no Estado. Ou seja, essas modalidades podem ou não "pegar", e isso depende de vários fatores. No caso do Brasil, em geral, a explicação mais comum reside na possibilidade de o empregador se valer do trabalho informal. No caso do setor automobilístico, certamente, não é esse o caso, mas pode ser no que se refere à construção civil.

Quanto aos novos padrões de negociação coletiva, nota-se que o SINTRICOM-JP se posicionou entre buscar evitar que, por essa via, se legitimem itens precarizantes da Reforma e tentar garantir a manutenção dos direitos já conquistados. Contudo, diante das investidas empresariais, a estratégia tem sido a de não fechar acordos, de modo que faz dois anos que a CCT não foi fechada, deixando os trabalhadores vulneráveis. Já o SINDMETAL-PE tem usado a estratégia bem sucedida de realizar 
ACT com a FCA de Goiana, mas se vê fragilizado para avançar na agenda sindical no Polo, por enfrentar severa posição antissindical da Jeep e das demais empresas, com dificuldade de se estabelecer entre os trabalhadores. Ao que tudo indica, as condições até agora mantidas se devem mais ao padrão (embora rebaixado na região) da indústria automobilística do que à organização dos trabalhadores. Já no que se refere ao SINDPD-PE, ele tem mantido o teor das conquistas anteriores, apesar das investidas empresariais.

Os três Sindicatos têm posição claramente contrária à Reforma Trabalhista, por seus efeitos nefastos sobre os trabalhadores e o próprio sindicalismo. Segundo seus dirigentes, tais efeitos se observam, principalmente, na queda significativa das homologações das rescisões contratuais sem a assistência sindical e no comprometimento das finanças sindicais, com o fim da contribuição sindical compulsória, além de dificuldades impostas à implementação de meios alternativos de financiamento.

Apesar da contundência das medidas adotadas, observam-se reações e resistências, fazendo com que "o jogo continue em aberto". Como nos lembra Polanyi (2000, p. 55):

Aquilo que é ineficaz para parar uma linha de desenvolvimento não é, por isto mesmo, totalmente ineficaz. O ritmo da mudança muitas vezes não é menos importante do que a direção da própria mudança; mas, enquanto essa última frequentemente não depende da nossa vontade, é justamente o ritmo no qual permitimos que a mudança ocorra que pode depender de nós.

Provavelmente, os conflitos, sob os novos parâmetros trazidos com a Reforma, tenderão a se manifestar com maior intensidade na medida em que suas consequências para os trabalhadores forem se fazendo sentir mais claramente. Cabe-nos continuar acompanhando e analisando, em especial, seus desdobramentos no caso do Nordeste.

Recebido para publicação em 20 de abril de 2019 Aceito em 21 de maio de 2019

\section{REFERÊNCIAS}

BALTAR, P. et al. Moving towards decent work: labour in the Lula government: reflections on recent Brazilian experience. Global labour university working papers, v. 9, n. 1 , p. 1-43, 2010

BOITO JR., A.; MARCELINO, P. O sindicalismo deixou a crise para trás? Um novo ciclo de greves na década de 2000. Caderno CRH, Salvador, v. 23 , n. 59, p. 323-338, maio/ago. 2010

CENTRO DE ESTUDOS SINDICAIS E DE ECONOMIA DO TRABALHO (CESIT). Dossiê Reforma trabalhista. Campinas: IE-UNICAMP, 2017.

DEPARTAMENTO INTERSINDICAL DE ESTATÍSTICA E ESTUDOS SOCIOECONOMICOS (DIEESE). Acompanhamento das Negociações Coletivas Pós-Reforma Trabalhista: relatório dos impactos no primeiro semestre de 2018. São Paulo: CUT: DIEESE, 2018. Disponível em: http://cedoc.cut.org.br/cedoc/livros-e-folhetos/6392. Acesso em: 15 abr. 2019.

KOUMENTA, M.; WILLIAMS, M. An anatomy of zerohour contracts in the united kingdom: conference paper. 2015. Disponível em: https://www.cipd.co.uk/Images/ an-anatomy-of-zero-hour-contracts-in-the-unitedkingdom_2015_tcm18-15580.pdf. Acesso em: 13 abr. 2019.

KREIN, D. Tendências recentes nas relações de emprego no Brasil - 1990/2005. 2007. Tese (Doutorado em Economia) - Instituto de Economia, Universidade Estadual de Campinas, Campinas, 2007.

KREIN, D.; GIMENEZ, D.; SANTOS, A. Dimensões críticas da Reforma trabalhista no Brasil. Campinas: Curt Nimuendajá, 2018.

LADOSKY, M. H. Notas sobre a experiência da classe trabalhadora e alguns desafios à ação sindical dos metalúrgicos no Polo Automotivo de Goiana - Pernambuco. In: SIMPÓSIO INTERNACIONAL TRABALHO, RELAÇÕES DE TRABALHO, EDUCAÇÃO E IDENTIDADE (SITRE). 7. 2018, Belo Horizonte. Anais [...] Belo Horizonte: UFMG: CEFET-MG, 2018. p. 87-102.

PASTORE, J. Reformas trabalhistas não são iguais. Correio Braziliense, 13 mar. 2017. Disponível em: http://www.josepastore. com.br/artigos/rt/rt_383.htm. Acesso em: 13 abr. 2019.

POLANYI, K. A grande transformação: as origens de nossa época. 2. ed. Rio de Janeiro: Campus, 2000.

REFORMA permite contratação de funcionário por R\$ 4,26 a hora. Veja, 27 out. 2017. Disponível em: https://veja. abril.com.br/economia/reforma-permite-contratacao-defuncionario-por-r-426-a-hora/. Acesso em: 13 abr. 2019

SCHERER, C. Diálogo e proteção social - a negociação coletiva após um ano de Reforma Trabalhista. In: SEMINÁRIO "UM ANO DE VIGÊNCIA DA REFORMA TRABALHISTA: EFEITOS E PERSPECTIVAS”. 2018, Brasília. Anais [...] Brasília: [S.n.], 2018.

SOPRANA, P. Especialistas veem com receio fala de Bolsonaro sobre informalidade. Folha de São Paulo, São Paulo, 13 dez. 2018. Disponível em: https://www1.folha. uol.com.br/mercado/2018/12/especialistas-veem-comreceio-fala-de-bolsonaro-sobre-informalidade.shtml. Acesso em: 13 abr. 2019.

VÉRAS DE OLIVEIRA, R. Trabalho no Nordeste em perspectiva histórica. Estudos avançados, São Paulo, v. 30, n. 87, p. 49-73, maio/ago. 2016.

VÉRAS DE OLIVEIRA, R. Brazilian labour reform in historical perspective. Global: labour journal, v. 9, n. 3, p. 319-339, 2018.

VÉRAS DE OLIVEIRA, R. Os trabalhadores de TI em Pernambuco: perfil exploratório de um segmento diferenciado. In: LEITE, M. P.; SALAS, C.; BIAVASCHI, M. (Org.). O trabalho em crise: flexibilidade e precariedade. São Carlos: EdUFSCar, 2019. 


\section{THE LABOR REFORM AND ITS IMPLICATIONS FOR THE NORTHEAST: first reflections}

\author{
Roberto Véras de Oliveira \\ Mário Henrique Ladosky \\ Maurício Rombaldi
}

\begin{abstract}
Motivated by the affirmation of the need of "modernizing" the labor relations in Brazil, the implementation of the Labor Reform in November 2017 meant a profound change in the paradigm of the labor regulation in Brazil. This article aims to analyze the effects of the Reform in the Northeast Brazil, just over a year after its implementation. In particular, it seeks to observe the extent to which this pattern of regulation has exacerbated social inequalities. Therefore, the focus of the study lies in three economic sectors of two states and their respective labor unions: in Paraíba, we approach the construction sector and, in Pernambuco, the automotive industry and the information technology segment. For the research, it was used data from PNADC/IBGE, RAIS, CAGED, Mediator/MTE, and questionnaires and interviews collected in a survey of the Network of Studies and Interdisciplinary Monitoring of Labor Reform (REMIR).
\end{abstract}

KEYwORDS: Labor Reform. Workers. Unions. Inequality. Northeast Brazil.

\section{RÉFORME DU TRAVAIL ET SES IMPLICATIONS POUR LE NORD-EST: premières réflexions}

\author{
Roberto Véras de Oliveira \\ Mário Henrique Ladosky \\ Maurício Rombaldi
}

Sous le discours de la nécessité d'une "modernisation" de las relations de travail au Brésil, la mise en œuvre de la réforme du travail en novembre 2017 a entraîné un changement profond du paradigme de la réglementation des relations de travail au pays. L'objectif de cet article est d'analyser les effets de la réforme dans le Nord-Est du Brésilien, un peu plus d'un an après son entrée en vigueur. En particulier, il cherche à observer dans quelle mesure ce mode de régulation a aggravé les inégalités sociales. Par conséquent, l'étude se concentre sur trois secteurs économiques de deux États et de leurs syndicats respectifs: à Paraíba, nous abordons le secteur de la construction et, à Pernambuco, les secteurs de l'automobile et des technologies de l'information. Pour la recherche, ont été utilisées les données de PNADC / IBGE, RAIS, CAGED, Mediator / MTE, ainsi que les questionnaires et entretiens collectés dans le cadre d'une enquête du réseau d'études et de suivi interdisciplinaire de la réforme du travail (REMIR).

Mots CLÉs: Réforme du travail. Les ouvriers. Les syndicats. L’inégalité. Nord-est du Brésil. Ciências Sociais e ao Programa de Pós-Graduação em Sociologia da Universidade Federal da Paraíba UFPB. Publicou Sindicalismo e democracia no Brasil: do novo sindicalismo ao sindicato cidadão. São Paulo: Annablume Editora, 2011. v. 1. 394p.

Mário Henrique Ladosky - Doutor em Sociologia pela USP. Professor na Unidade Acadêmica de Ciências Sociais e do Programa de Pós-Graduação em Ciências Sociais (PPGCS) da UFCG. Em 2018 publicou os artigos A CUT e o sindicalismo brasileiro nos anos recentes: limites e possibilidades, na Revista Tempo Social; Das greves do ABC ao Conselho de Relações de Trabalho: chances e limites da ação sindical. Revista Lua Nova; Organizzazione del lavoro e relazioni di lavoro nel Polo Automobilistico del Pernambuco: l'applicazione del WCM alla FCA di Goiana. Revista Sociologia del Lavoro

Maurício Rombaldi - Doutor em Sociologia pela USP. Pós-Doutorado pela Universidade Federal do Rio Grande do Sul. Professor vinculado ao Departamento de Ciências Sociais e ao Programa de PósGraduação em Sociologia da Universidade Federal da Paraíba - UFPB. Editor associado da área de sociologia da Revista Brasileira de Ciências Sociais (RBCS/ANPOCS). Publicações recentes: Campañas por Trabajo Decente en Megaeventos Deportivos en Brasil: estrategias sindicales innovadoras en el sector de la construcción. Revista Nueva Sociedad, p. 165-187, 2017; Diferentes ritmos da internacionalização sindical brasileira: uma análise dos setores metalúrgico e de telecomunicações. Caderno CRH, v. 29, p. 535-552, 2016. 